\title{
In Vitro and In Vivo Anti-Inflammatory Evaluation of the Whole Plant Extracts of Crotalaria Biflora (L)
}

\author{
K. I. Anoob Kumar ${ }^{1, *}$, M. Swamivel Manickam ${ }^{2}$, M. Sreejith ${ }^{3}$, V. Sebastin ${ }^{4}$
}

K. I. Anoob Kumar ${ }^{1, *}$, M. Swamivel Manickam², M. Sreejith ${ }^{3}$, V. Sebastin $^{4}$

'Department of Pharmaceutical Chemistry, KVM College of Pharmacy, Cherthala, Alappuzha, Kerala, INDIA.

${ }^{2}$ Department of Pharmacy, Annamalai

University, Annamalai Nagar, Chidambaram, Tamil Nadu, INDIA.

${ }^{3}$ Department of Pharmaceutical Chemistry, Nazareth College of Pharmacy, Thiruvalla, Pathanamthitta, Kerala, INDIA.

${ }^{4}$ Department of Pharmaceutical Chemistry, Malik Deenar College of Pharmacy, Seethangoli, Kasaragod, Kerala, INDIA

\section{Correspondence}

\section{K. I. Anoob Kumar}

Associate Professor, Department of Pharmaceutical Chemistry, KVM College of Pharmacy, Cherthala, Alappuzha, Kerala, INDIA

E-mail: anoobkumarki@gmail.com

History

- Submission Date: 15-12-2020;

- Review completed: 13-01-2021;

- Accepted Date: 15-02-2021.

DOI : 10.5530/pj.2021.13.78

Article Available online http://www.phcogj.com/v13/i3

\section{Copyright}

(C) 2021 Phcogj.Com. This is an openaccess article distributed under the terms of the Creative Commons Attribution 4.0 International license.

\section{ABSTRACT}

Background: Several species of Crotalaria are cultivated and consumed across the world by the rural population for a variety of purposes that include medicine, food, green manure, fodder etc. Objective: The present study was aimed to evaluate the anti-inflammatory activity of different extracts of the whole plant Crotalaria biflora by in vitro and in vivo methods. Materials and Methods: The powdered material of the whole plant Crotalaria biflora was extracted by soxhelation with different solvents such as petroleum ether, chloroform, ethyl acetate and methanol. Stabilization of human red blood cell (HRBC) membrane is the method employed for the in vitro evaluation. The extracts selected based on the results of in vitro evaluation was further subjected to in vivo evaluation by carrageenan-induced rat paw oedema method. In both in vitro and in vivo evaluations, Indomethacin was used as the standard control. Results: Among the four tested extracts in six different concentrations subjected to the in vitro evaluation, the ethyl acetate and methanol extracts $(1000 \mu \mathrm{g} / \mathrm{ml})$ showed significant activity which was selected for the in vivo evaluation. Among the two doses of extracts $\left(200 \mathrm{mg}^{\mathrm{kg}} \mathrm{kg}^{-1}\right.$ and $400 \mathrm{mg}^{\mathrm{kg}} \mathrm{kg}^{-1}$ ) selected for the in vivo evaluation, the methanol extract $\left(400 \mathrm{mg} \cdot \mathrm{kg}^{-1}\right.$ ) showed significant activity followed by the ethyl acetate extract in the same dose. Conclusion: Further studies on the phytochemicals present in these extracts may give more significant results Key words: Crotalaria biflora extracts, In vitro anti-inflammatory evaluation, In vivo antiinflammatory evaluation.

\section{INTRODUCTION}

The first documented data of genus Crotalaria was done by Carolus Linnaeus in the year 1753 . He described 13 species belong to this genus in his Species Plantarum. They are C. albanand L., C. juncea L., C. lunaris L., C. laburnifolia L., C. lotifolia L., C. micans L., Crotalaria perfoliata L., C. quinquefolia L., C. sagitalis L., C. triflora L., C. villosa $\mathrm{L}$., C. verrucosa $\mathrm{L}$. Thereafter the number of species within this genus increased and now it reaches of about 702 species in global distribution mainly in tropical Africa and Madagascar and secondary radiations in rests of the world..$^{1-3}$ The genus Crotalaria is very diverse and extensively distributed which includes perennial aquatic herbs, erect herbs and shrubs, terrestrial creepers as well as trees can be found in diverse habitats viz., open places, forest and grasslands, plains and hill regions. In India Crotalaria constitute largest legume genera represented by 116 taxa in which 52 are endemic to the country with the maximum species concentration in the peninsular region (73 species restricted to the peninsular region). ${ }^{2}$ Several species of Crotalaria are cultivated and consumed across the world by the rural population for variety of purposes that include medicine, food, green manure, fodder etc. ${ }^{4}$ The plant Crotalaria biflora, one among them commonly found in south India at an altitude up to $300 \mathrm{~m}$ mean sea level, the seed of this plant is edible and consumed by rural population because of its protein content. ${ }^{5,6}$ In our previous study, ${ }^{7}$ the whole plant of Crotalaria biflora was collected from the Mekkarai, the village located near the foothills of Western Ghats, Tirunelveli District, Tamil Nadu, India. The collected material was subjected to extraction, preliminary phytochemical evaluation and spectral characterization. The present study was aimed to evaluate the in vitro and in vivo anti-inflammatory activity of the extracts of the whole plant Crotalaria biflora.

\section{MATERIALS AND METHODS}

\section{Collection and extraction of plant material}

The whole plant of Crotalaria biflora was collected from the Mekkarai, a village close to the foothills of the Western Ghats in Tirunelveli District of Tamil Nadu, India. The collected plant material was identified, authenticated and subjected to shade drying and powdering by mechanical grinding. The coarse powder thus obtained was extracted by soxhelation using the solvents such as petroleum ether, chloroform, ethyl acetate, and methanol.? The dried extracts thus obtained were used for the evaluation of anti-inflammatory activity.

In vitro evaluation of anti-inflammatory activity

Anti-inflammatory activity of all the prepared extracts was evaluated in vitro by stabilization of human red blood cell (HRBC) membrane in normal and different temperature and tonicity conditions in reference to the previous literature ${ }^{8-11}$. All assays were done in triplicate and the results were expressed as mean \pm standard deviation. 


\section{HRBC membrane stabilization method}

An equal volume of freshly collected whole human blood from the healthy volunteers and the sterile Alsever solution (2\% dextrose, $0.8 \%$ sodium citrate, $0.05 \%$ citric acid, $0.42 \%$ sodium chloride $/ 100 \mathrm{ml}$ distilled water) was mixed and subjected to centrifugation (3000 rpm for $10 \mathrm{~min})$. The packed cells thus obtained was washed and reconstituted as $10 \% \mathrm{v} / \mathrm{v}$ suspension by using sterile isosaline $\left(0.85 \% \mathrm{NaCl}\right.$ in $\mathrm{H}_{2} \mathrm{O}$ sterilized by autoclaving). $1 \mathrm{ml}$ of HRBC suspension and $1 \mathrm{ml}$ of each test extracts in different concentration $(100,200,400,600,800,1000 \mu \mathrm{g} /$ $\mathrm{ml}$ ) was taken in the individual tubes. Normal (HRBC suspension and Alsever solution only) and standard control (Indomethacin $100 \mu \mathrm{g} / \mathrm{ml}$ instead of test extracts) were prepared. All the tubes were incubated for $30 \mathrm{~min}$ at $37^{\circ} \mathrm{C}$, followed by subjected to centrifugation. The supernatant was collected and its haemoglobin content was estimated spectrophotometrically $(560 \mathrm{~nm})$ and the percentage haemolysis and protection were calculated by

Percentage of haemolysis $=\frac{O D \text { of test }}{O D \text { of control }} \times 100$
Percentage of protection $=100-\frac{O D \text { of test }}{O D \text { of control }} \times 100$

OD of test-Optical density of tested extracts; OD of control-Optical density of normal control

\section{Temperature-induced haemolysis}

Test extracts dissolved in isotonic phosphate buffer solution was used for the experiments. The reaction mixture contains $5 \mathrm{ml}$ of test extracts in different concentration $(100,200,400,600,800,1000 \mu \mathrm{g} / \mathrm{ml})$ and $0.1 \mathrm{ml}$ of $10 \% \mathrm{v} / \mathrm{v}$ HRBC suspension. Normal control contains saline and the standard control contains $100 \mu \mathrm{g} / \mathrm{ml}$ of Indomethacin instead of test extracts. A set of prepared tubes was kept at $54^{\circ} \mathrm{C}$ for $20 \mathrm{~min}$. in a regulated water bath. Another set of the tube was kept at $-10^{\circ} \mathrm{C}$ for $20 \mathrm{~min}$ in a freezer. Then, all the tubes were centrifuged (3000rpm for $3 \mathrm{~min}$ ), supernatant was collected and the haemoglobin content was estimated spectrophotometrically $(540 \mathrm{~nm})$ and from this the percentage inhibition of haemolysis by the tests was calculated by

Percentage inhibition of haemolysis $=1-\frac{\text { OD. } 2-\text { OD. } 1}{\text { OD. } 3-\text { OD. } 1} \times 100$ OD.1-Optical density of tests cooled; OD.2-Optical density of tests heated; OD.3-Optical density of normal control heated

\section{Tonicity induced haemolysis}

Test extracts dissolved in hypotonic ( $0.2 \%$ sodium chloride) and isotonic solution ( $0.9 \%$ sodium chloride) were used for the experiments. Both hypotonic and isotonic reaction mixture contains $5 \mathrm{ml}$ of test extracts in different concentration $(100,200,400,600,800,1000 \mu \mathrm{g} / \mathrm{ml})$ and $0.1 \mathrm{ml}$ of $10 \% \mathrm{v} / \mathrm{v}$ HRBC suspension. Normal control contains distilled water and the standard control contains Indomethacin $100 \mu \mathrm{g} / \mathrm{ml}$ instead of test extracts. All the prepared tubes were kept in incubation at $37^{\circ} \mathrm{C}$ for $1 \mathrm{hr}$ and then centrifuged at $3000 \mathrm{rpm}$ for $3 \mathrm{~min}$. The supernatant was collected and its haemoglobin content was estimated spectrophotometrically $(540 \mathrm{~nm})$ and the percentage inhibition of haemolysis was calculated by

Percentage inhibition of haemolysis $=1-\frac{\text { OD. } 2-\text { OD. } 1}{\text { OD. } 3-\text { OD. } 1} \times 100$

OD.1-Optical density of tests in isotonic solution; OD.2-Optical density of tests in hypotonic solution; OD.3-Optical density of normal control in hypotonic solution

\section{In vivo evaluation of anti-inflammatory activity}

Based on the results of in vitro evaluation, the extracts selected were subjected to in vivo evaluation in the experimental animals with paw oedema induced by carrageenan. The evaluation was done in reference to the previous literature. ${ }^{12-14}$

Healthy young adult male Albino Wistar rats of about $180-200 \mathrm{~g}$ received from the Central animal house of Cape Bio Lab \& Research Centre, Marthandam, Kanyakumari, Tamil Nadu, India, were used for the study which was approved by the institutional animal ethics committee (CBLRC/IAEC/01/01-2020). All the animal experiments were done by the guidelines of a committee for the purpose of control and supervision on experiments on animals (OECD 423). The animals selected were housed in appropriate temperature $\left(25 \pm 1^{\circ} \mathrm{C}\right)$, humidity $(55 \pm 3 \%)$ and $12 \mathrm{~h}$ light/dark cycle and fed with commercial diet and water ad libitum.

Experimental animals were divided into 7 groups of 6 each. Group I is normal control administered with saline $\left(5 \mathrm{ml} \cdot \mathrm{kg}^{-1}\right)$. Group II is inflammatory control treated with carrageenan. Group III is standard control treated with Indomethacin $\left(10 \mathrm{mg} \cdot \mathrm{kg}^{-1}\right)$. Group IV and V are treatment control received the ethyl acetate extract in the dose of 200 and $400 \mathrm{mg} . \mathrm{kg}^{-1}$ respectively. Group VI and VII are the treatment control received methanol extract in 200 and $400 \mathrm{mg}^{-\mathrm{kg}^{-1}}$ respectively. Thirty minutes before the administration of standard drug/test extracts, $0.1 \mathrm{ml}$ of $1 \% \mathrm{w} / \mathrm{v}$ inj. carrageenan in saline $(0.1 \mathrm{ml})$ was administered in the sub-plantar region in the right hind paw of the animals of the entire group except normal control. The standard drug and the test extracts were administered to the animals of entire group by intraperitoneal injection except for normal and inflammatory control.

The paw volume of the injected animal was started to measure from zero hours by plethysmometrically and continued at the interval of one hour for five hours. The percentage inhibition of inflammation was calculated by

Percentage inhibition of inflammation $=\frac{V c-V t}{V c} \times 100$

Where, Vc-mean increase in paw volume in a control group of rats; $\mathrm{Vt}-\mathrm{mean}$ increase in paw volume in rats treated with test extracts

The results were expressed in mean \pm SEM (Standard Error Mean) 6 experimental animals in each group. Statistical significance was assessed by ANOVA and Dunnett's test. P-values $<.05$ were considered significant.

\section{RESULTS AND DISCUSSION}

Table 1 shows the results of HRBC membrane stabilization assay. From the results, it was observed that the tested extracts showed a concentration-dependent rise of activity which was clearly indicated by the ethyl acetate extract $(1000 \mu \mathrm{g} / \mathrm{ml})$ with the percentage protection of $74.11 \pm 0.26$, followed by the methanol extract in the same concentration revealed percentage protection of $66.20 \pm 1.65$

Stabilization of HRBC membrane in different temperature viz., heat $\left(54^{\circ} \mathrm{C}\right)$ and cold $\left(-10^{\circ} \mathrm{C}\right)$ conditions are presented in Table 2 . The results showed a concentration-dependent rise in activity of tested extracts. From the results it was found that the methanol extract $(1000 \mu \mathrm{g} / \mathrm{ml})$ in cold condition showed a maximum activity with the score of $78.80 \pm 1.40$ percentage inhibition of haemolysis. Next to that the ethyl acetate extract in heated condition revealed a percentage inhibition of $75.20 \pm 1.30$ and followed by methanol extract with the score of $64.30 \pm 1.70$ percentage inhibition of haemolysis. The standard drug Indomethacin $(100 \mu \mathrm{g} / \mathrm{ml})$ showed $65.20 \pm 0.75$ and $68.30 \pm 1.80$ percentage inhibition of haemolysis in heated and cold condition respectively.

The results of HRBC membrane stabilization in different tonicity viz., hypotonic and isotonic condition was presented in Table 3 . In this evaluation also a concentration-dependent rise of activity of extracts was observed. Maximum activity was found in ethyl acetate extract $(1000 \mu \mathrm{g} / \mathrm{ml})$ in isotonic condition with the percentage inhibition 
Table 1: Effect of test extracts on the protection of HRBC membrane.

\begin{tabular}{|c|c|c|c|c|}
\hline \multirow{2}{*}{ Concentration $(\mu \mathrm{g} / \mathrm{ml})$} & \multicolumn{4}{|c|}{$\%$ Protection } \\
\hline & Pet. Ether & Chloroform & Ethyl acetate & Methanol \\
\hline 100 & $05.31 \pm 0.28$ & $07.45 \pm 0.92$ & $11.54 \pm 0.72$ & $8.36 \pm 1.56$ \\
\hline 200 & $08.89 \pm 0.58$ & $11.36 \pm 1.01$ & $15.20 \pm 0.14$ & $22.51 \pm 2.07$ \\
\hline 400 & $15.67 \pm 0.67$ & $16.52 \pm 0.53$ & $36.58 \pm 1.55$ & $31.25 \pm 2.56$ \\
\hline 600 & $28.69 \pm 1.12$ & $35.21 \pm 2.32$ & $51.49 \pm 1.95$ & $43.23 \pm 1.58$ \\
\hline 800 & $41.26 \pm 1.76$ & $48.29 \pm 1.90$ & $66.59 \pm 0.78$ & $63.72 \pm 0.87$ \\
\hline 1000 & $52.22 \pm 1.30$ & $55.30 \pm 1.50$ & $74.11 \pm 0.26$ & $66.20 \pm 1.65$ \\
\hline 100 (Indomethacin) & $71.62 \pm 1.32$ & & & \\
\hline
\end{tabular}

Table 2: Effect of test extracts on the protection of cell membrane in different temperature condition.

\begin{tabular}{|c|c|c|c|c|c|c|c|c|}
\hline \multirow{2}{*}{ Con. $(\mu \mathrm{g} / \mathrm{ml})$} & \multicolumn{8}{|c|}{$\%$ inhibition of haemolysis } \\
\hline & \multicolumn{4}{|c|}{ Heat $\left(54^{\circ} \mathrm{C}\right)$} & \multicolumn{4}{|c|}{ Cold $\left(-10^{\circ} \mathrm{C}\right)$} \\
\hline Normal control & \multicolumn{4}{|c|}{$29.50 \pm 1.52$} & \multicolumn{4}{|c|}{$31.32 \pm 0.90$} \\
\hline Extracts & 1 & 2 & 3 & 4 & 1 & 2 & 3 & 4 \\
\hline 100 & $18.85 \pm 0.75$ & $21.26 \pm 0.59$ & $39.00 \pm 1.60$ & $17.27 \pm 1.10$ & $18.58 \pm 0.78$ & $20.30 \pm 0.60$ & $40.50 \pm 1.10$ & $35.50 \pm 0.30$ \\
\hline 200 & $24.69 \pm 0.85$ & $27.57 \pm 0.51$ & $41.22 \pm 0.90$ & $26.50 \pm 1.50$ & $27.52 \pm 0.88$ & $28.81 \pm 0.70$ & $43.70 \pm 1.30$ & $42.70 \pm 0.50$ \\
\hline 400 & $30.50 \pm 1.20$ & $33.21 \pm 0.75$ & $49.70 \pm 0.83$ & $37.80 \pm 2.00$ & $36.10 \pm 0.71$ & $34.64 \pm 1.20$ & $47.10 \pm 0.80$ & $51.90 \pm 0.85$ \\
\hline 800 & $42.20 \pm 1.52$ & $44.28 \pm 2.20$ & $71.60 \pm 0.70$ & $56.42 \pm 2.30$ & $48.60 \pm 0.11$ & $44.40 \pm 1.32$ & $56.70 \pm 0.70$ & $69.60 \pm 1.20$ \\
\hline 1000 & $47.85 \pm 1.00$ & $57.60 \pm 2.08$ & $75.20 \pm 1.30$ & $64.30 \pm 1.70$ & $51.50 \pm 1.11$ & $52.28 \pm 1.15$ & $61.50 \pm 1.10$ & $78.80 \pm 1.40$ \\
\hline 100 (Std.) & $65.20 \pm 0.75$ & & & & $68.30 \pm 1.80$ & & & \\
\hline
\end{tabular}

Con. - Concentration; Std. - Standard (Indomethacin); 1 - Petroleum ether; 2 - Chloroform; 3 - Ethyl acetate; 4 - Methanol

Table 3: Effect of test extracts on the protection of cell membrane in different tonicity condition.

\begin{tabular}{|c|c|c|c|c|c|c|c|c|}
\hline \multirow{2}{*}{ Con. ( $\mu \mathrm{g} / \mathrm{ml})$} & \multicolumn{8}{|c|}{$\%$ inhibition of haemolysis } \\
\hline & \multicolumn{4}{|c|}{ Hypotonic solution } & \multicolumn{4}{|c|}{ Isotonic solution } \\
\hline Normal control & \multicolumn{4}{|c|}{$08.30 \pm 0.32$} & \multicolumn{4}{|c|}{$06.25 \pm 0.80$} \\
\hline Extracts & 1 & 2 & 3 & 4 & 1 & 2 & 3 & 4 \\
\hline 100 & $07.32 \pm 0.15$ & $10.60 \pm 0.61$ & $10.06 \pm 0.90$ & $10.80 \pm 0.20$ & $10.86 \pm 0.87$ & $12.03 \pm 0.40$ & $18.50 \pm 0.30$ & $17.10 \pm 0.50$ \\
\hline 200 & $12.19 \pm 0.59$ & $15.50 \pm 0.21$ & $31.40 \pm 0.60$ & $20.30 \pm 0.10$ & $16.32 \pm 0.79$ & $19.19 \pm 0.20$ & $27.30 \pm 0.50$ & $20.80 \pm 0.80$ \\
\hline 400 & $17.30 \pm 0.30$ & $18.12 \pm 0.55$ & $32.60 \pm 0.40$ & $27.50 \pm 0.70$ & $20.10 \pm 0.61$ & $22.60 \pm 0.20$ & $34.40 \pm 0.70$ & $26.40 \pm 0.70$ \\
\hline 800 & $25.50 \pm 0.72$ & $24.20 \pm 1.23$ & $50.20 \pm 0.40$ & $36.10 \pm 0.60$ & $28.50 \pm 0.15$ & $29.26 \pm 0.24$ & $47.70 \pm 0.40$ & $37.50 \pm 0.60$ \\
\hline 1000 & $27.25 \pm 0.70$ & $25.10 \pm 1.81$ & $57.10 \pm 0.60$ & $51.40 \pm 0.30$ & $31.30 \pm 0.11$ & $32.81 \pm 0.32$ & $73.10 \pm 0.90$ & $46.30 \pm 0.90$ \\
\hline 100 (Std.) & $72.50 \pm 0.70$ & & & & $86.8 \pm 0.50$ & & & \\
\hline
\end{tabular}

Con. - Concentration; Std. - Standard (Indomethacin); 1 - Petroleum ether; 2 - Chloroform; 3 - Ethyl acetate; 4 - Methanol

of haemolysis of $73.10 \pm 0.90$. But the same extract showed a score of $57.10 \pm 0.60$ percentage inhibition of haemolysis in hypotonic condition. Next to that the methanol extract showed significant results. But it showed a maximum activity in hypotonic condition with the percentage inhibition of haemolysis of $51.40 \pm 0.30$. In the isotonic condition, the same extract showed a less score of $46.30 \pm 0.90$ comparing with hypotonic of it.

From the results of in vitro anti-inflammatory evaluation, it was found that the ethyl acetate and methanol extract of C. biflora showed significant activity, particularly the ethyl acetate extract. It was also confirmed that the concentration of the extracts, the differences in the environmental conditions such as temperature and tonicity plays an important role in the findings. It is well known that normally the cell membrane plays an important role in the viability of cell. Exposure of red blood cells to diverse adverse conditions such as heat, cold and hypotonicity, induces free radicals formation which in turn activates the lipid peroxidation that makes the cell heavily susceptible to secondary damage and the released inflammatory mediators elevate the cell membrane permeability that causes leakage of serum proteins and fluids into the cells. But it can be prevented by the stabilization of cell membrane. In this study, the ethyl acetate and methanol extracts of C. biflora revealed a significant $\mathrm{RBC}$ membrane stabilization comparing with the standard drug Indomethacin. It may be due to the blocking of release of inflammatory mediators and lytic enzymes. A previous literature ${ }^{15}$ reported that the saponins and flavonoids possess a significant effect on lysosomal membrane stabilization in both in vitro and in vivo evaluation. Our study on the phytochemical evaluation of the extracts of $C$. biflora revealed the presence saponins and flavonoids in the ethyl acetate and methanol extract ${ }^{7}$ which may be responsible for their activity in the in vitro evaluation.

Based on the results of in vitro evaluation, the ethyl acetate and methanol extracts were selected for the in vivo evaluation in the paw oedema induced by administering the carrageenan to the experimental animals. The results showed that in case of Group I animals (normal control), there was no significant difference between the initial paw volume and the paw volume in each hour of observation. But, in case of Group II (inflammatory control) animals, the paw volume was in elevation in each hour of observation. The first-hour observation of Group III (standard control) animals revealed a slight elevation of paw volume from its initial level. However in subsequent observations, it was reduced constantly and ended in the minimum in $5^{\text {th }}$ hour (last) observation. Similar results were found in the animals received ethyl 
Table 4: Effect of Crotalaria biflora extracts in paw volume in carrageenan-induced paw oedema in rat.

\begin{tabular}{|c|c|c|c|c|c|c|}
\hline \multirow[t]{2}{*}{ Group } & \multicolumn{6}{|c|}{ Paw volume (ml) } \\
\hline & $\mathrm{Oh}$ & $1 \mathrm{~h}$ & $2 \mathrm{~h}$ & $3 h$ & $4 h$ & $5 \mathrm{~h}$ \\
\hline I & $0.40 \pm 0.25$ & $0.57 \pm 0.14$ & $0.54 \pm 0.13$ & $0.52 \pm 0.05$ & $0.51 \pm 0.07$ & $0.46 \pm 0.06$ \\
\hline II & $0.49 \pm 0.02$ & $0.54 \pm 0.03$ & $0.69 \pm 0.03$ & $0.71 \pm 0.02$ & $0.70 \pm 0.02$ & $0.68 \pm 0.01$ \\
\hline III & $0.49 \pm 0.01$ & $0.52 \pm 0.02$ & $0.50 \pm 0.02$ & $0.48 \pm 0.03$ & $0.43 \pm 0.02$ & $0.42 \pm 0.02$ \\
\hline IV & $0.46 \pm 0.02$ & $0.51 \pm 0.01$ & $0.48 \pm 0.02^{\star *}$ & $0.43 \pm 0.02^{\star *}$ & $0.42 \pm 0.02^{\star *}$ & $0.40 \pm 0.01^{\star *}$ \\
\hline $\mathrm{V}$ & $0.45 \pm 0.02$ & $0.53 \pm 0.02$ & $0.50 \pm 0.02^{\star *}$ & $0.49 \pm 0.02^{* * *}$ & $0.47 \pm 0.02^{\star \star \star *}$ & $0.41 \pm 0.01^{\star * *}$ \\
\hline VI & $0.45 \pm 0.09$ & $0.48 \pm 0.11$ & $0.46 \pm 0.12^{* * *}$ & $0.44 \pm 0.18^{\star * *}$ & $0.41 \pm 0.15^{\star * *}$ & $0.38 \pm 0.21^{\star * *}$ \\
\hline VII & $0.47 \pm 0.08$ & $0.50 \pm 0.06$ & $0.48 \pm 0.02^{* * *}$ & $0.46 \pm 0.03^{* * *}$ & $0.45 \pm 0.04^{* * *}$ & $0.43 \pm 0.01^{\star * *}$ \\
\hline
\end{tabular}

Group I-Normal control; Group II-Inflammatory control; Group III-Standard control; Group IV-Ethyl acetate extract 200mg.kg-1; Group V-Ethyl acetate extract 400mg.kg ${ }^{-1}$; Group VI-Methanol extract 200mg.kg ${ }^{-1}$; Group VII-Methanol extract 400mg.kg-1

\begin{tabular}{|c|c|c|c|c|c|c|}
\hline \multirow[t]{2}{*}{ Group } & \multicolumn{6}{|c|}{ \% inhibition } \\
\hline & $\mathrm{Oh}$ & $1 \mathrm{~h}$ & $2 \mathrm{~h}$ & $3 \mathrm{~h}$ & $4 \mathrm{~h}$ & $5 \mathrm{~h}$ \\
\hline III & $3.71 \pm 0.15$ & $1.85 \pm 0.09$ & $27.30 \pm 1.70$ & $33.25 \pm 1.26$ & $38.90 \pm 1.91$ & $41.28 \pm 2.58$ \\
\hline IV & $5.31 \pm 1.40$ & $6.52 \pm 1.81$ & $28.65 \pm 2.82^{* * *}$ & $37.18 \pm 0.34^{\star * *}$ & $38.95 \pm 1.58^{\star * *}$ & $36.41 \pm 1.35^{* * *}$ \\
\hline $\mathrm{V}$ & $7.45 \pm 0.36$ & $2.48 \pm 0.76$ & $25.96 \pm 1.80^{* * *}$ & $32.86 \pm 1.50^{* * *}$ & $33.12 \pm 1.20^{\star * *}$ & $36.65 \pm 1.33^{* * *}$ \\
\hline VI & $4.5 \pm 1.64$ & $6.70 \pm 1.53$ & $27.24 \pm 1.36^{\star * *}$ & $34.30 \pm 1.77^{\star \star \star}$ & $34.56 \pm 1.28^{\star * *}$ & $35.71 \pm 2.72^{* * *}$ \\
\hline VII & $7.15 \pm 0.60$ & $10.35 \pm 1.48$ & $30.74 \pm 1.18^{* * *}$ & $40.31 \pm 0.45^{\star * *}$ & $42.29 \pm 1.06^{* * *}$ & $39.59 \pm 1.35^{* * *}$ \\
\hline
\end{tabular}

Group III-Standard control; Group IV-Ethyl acetate extract 200mg.kg-1; Group V-Ethyl acetate extract 400mg.kg-1 ; Group VI-Methanol extract $200 \mathrm{mg} . \mathrm{kg}^{-1}$; Group VII-Methanol extract $400 \mathrm{mg} \cdot \mathrm{kg}^{-1}$

acetate and methanol extracts (Group IV-VII). From the results, it was found that both methanol and ethyl acetate extracts in the dose of $400 \mathrm{mg} \cdot \mathrm{kg}^{-1}$ showed significant activity comparing with the standard control drug, Indomethacin. (Tables 4 \& 5).

All values are expressed as mean \pm SEM for 6 animals in each group; ${ }^{\star} \mathrm{P}<0.05,{ }^{*} \mathrm{P}<0.01$ compared

\section{CONCLUSION}

In the present study, the whole plant of Crotalaria biflora was collected. After identification and authentication, the collected material was dried, powdered and extracted by soxhelation with solvents such as petroleum ether, chloroform, ethyl acetate, and methanol. All the dried extracts thus obtained were evaluated for the anti-inflammatory activity by in vitro and in vivo methods. Based on the results of in vitro evaluation, the ethyl acetate and methanol extracts were selected for the in vivo evaluation. In this evaluation, comparing with the standard drug, the methanol extract showed a significant activity followed by the ethyl acetate extract. A detailed study on the phytochemicals present in these extracts in the future may give more significant results.

\section{ACKNOWLEDGEMENT}

We would like to thank Mr J. Kumaran, M. Pharm., (Pharmaceutical Biotechnology), for his assistance in the preparation of this manuscript.

\section{CONFLICTS OF INTEREST}

None.

\section{FUNDING}

None.

\section{REFERENCES}

1. Samaila SY. A review of the genus Crotalaria L. (Crotalarieae, Fabaceae) IJSRP. 2018;8(6):316-21.
2. Rokade K, Dalavi JV, Gaikwad S, Gaikwad N. Crotalaria shrirangiana (Fabaceae): A new rattlepod from the Western Ghats of India. Phytotaxa. 2020;449(2):188-94.

3. Le Roux MM, Boatwright JS, Van Wyk BE. A global infrageneric classification system for the genus Crotalaria (Leguminosae) based on molecular and morphological evidence. Taxon. 2013;62(5):957-71.

4. Rouamba A, Ouedraogo V, Karama I, Compaore M, Kiendrebeogo M. Ethno-medicinal use of Crotalaria retusa L. (Fabaceae), a Pyrrolizidine alkaloid toxic plant. Int J Biochem Res Rev. 2018;23(2):1-6.

5. Sundararajan G, Preamkumar K. Ethnobotanical survey of medicinal plants used by traditional healers in Krishnagiri District of Tamil Nadu. Int J Sci Res. 2018;7(11):216-22.

6. Gritto MJ, Nanadagopalan V, Doss A. Ethnobotanical survey of medicinal plants used by Traditional healers in Shobanapuram village of Pachamalai Hill, Tamilnadu. Adv Appl Sci Res. 2015;6(3):157-64

7. Anoob Kumar KI, Swamivel Manickam M, Sreejith M, Sebastin V. Preliminary phytochemical evaluation, isolation and spectroscopic characterization of constituents in the dried extracts of the whole plant Crotalaria Biflora (L). Int J Life Sci Pharma Res. 2020:10(5): P124-33.

8. Seema CC, Sharan SV, Srinivasa RB, Meena V. In vitro anti inflammatory activity of methanolic extract of Centella asiatica by HRBC membrane stabilization. Rasayan J Chem. 2011;4(2):457-60.

9. Anosike CA, Obidoa O, Ezeanyika LU. Membrane stabilization as a mechanism of the anti-inflammatory activity of methanol extract of garden egg (Solanum aethiopicum). DARU J Pharm Sci. 2012;20(1):76.

10. Chowdhury A, Azam S, Jainul MA, Faruq KO, Islam A. Antibacteria activities and in vitro anti-inflammatory (membrane stability) properties of methanolic extracts of Gardenia coronaria leaves. Int J Microbiol. 2014; Article ID 410935.

11. Patel D, Desai S. Phytochemical screening, in vitro anti-microbial and anti-inflammatory activity of methanolic extract of Aster lanceolatus willd leaves. Int J Med Res. 2016;1(1):26-30.

12. Neha MPV, Suganthi $V$, Gowri S. Evaluation of anti-inflammatory activity in ethanolic extract of Coriandrum sativum L. using carrageenan induced paw oedema in albino rats. Der Pharma Chem. 2013;5(2):139-43. 
13. Arul K, Smith AA. In-silico design, synthesis and in vivo antiinflammatory evaluation of novel 1,2,4 - triazole derivatives. Int J Pharm Sci Rev Res. 2017;47(1):95-9.

14. Gupta R, Gupta GD. Formulation development and evaluation of antiinflammatory potential of Cordia obliqua topical gel on animal model. Pharmacog J. 2017;9(6)Suppl:s93-s8.
15. Oyedapo OO, Akinpelu BA, Akinwunmi KF, Adeyinka MO, Sipeolu FO. Red blood cell membrane stabilizing potentials of extracts of Lantana camara and its fractions. Int J Plant Physiol Biochem. 2010;2(4):46-51.

\section{GRAPHICAL ABSTRACT}

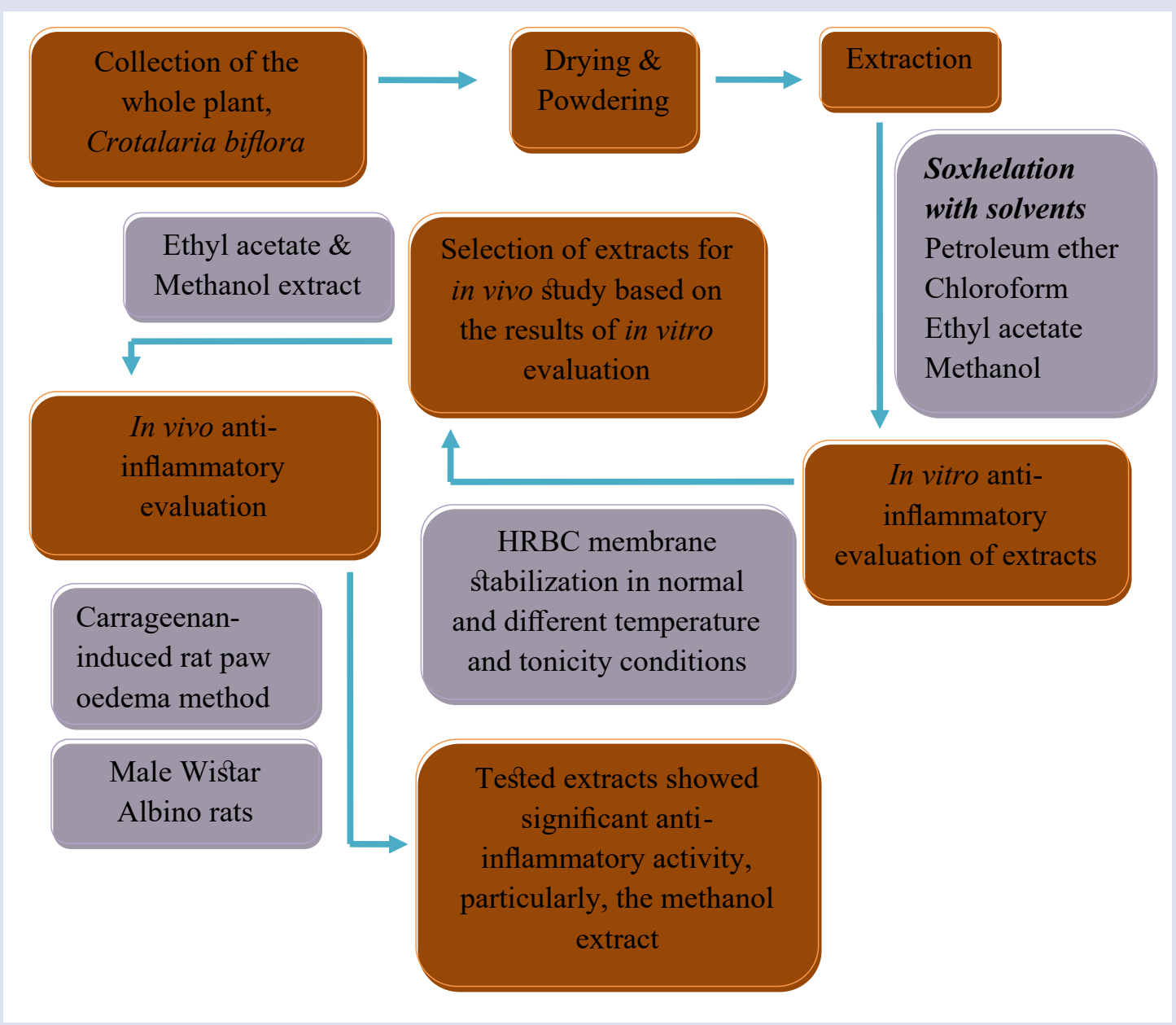

\section{ABOUT AUTHORS}

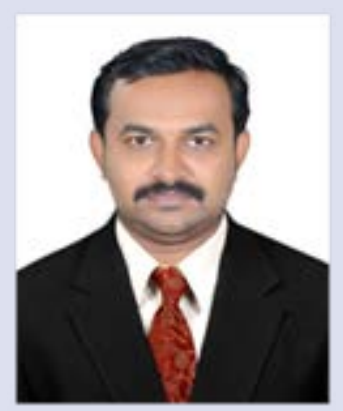

Anoob Kumar KI. He is an Associate Professor in Pharmaceutical Chemistry, currently working at KVM College of Pharmacy, Kerala, India. He is a lifetime member of the Association of Community Pharmacists of India. His research articles are published in various reputed national and international journals. He conducted and chaired many seminars in Pharmaceutical chemistry. 

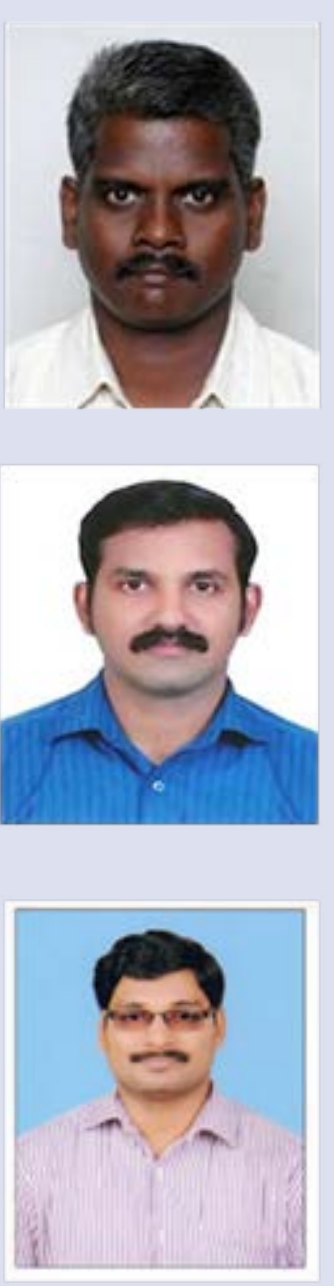

Dr Swamivel Manickam M. M. Pharm., Ph. D., Associate Professor in the Department of Pharmacy, Annamalai University, India., has seventeen years of teaching and eleven years of research experience. He is a life member of IPGA Tamil Nadu, and has published several research articles in reputed international journals and poster presentation of research information in many national and international level academic conferences. He guided many graduate and postgraduate students in their research projects and now guiding four Doctoral program scholars.

Dr Sreejith M. M. Pharm., Ph. D., Professor in Pharmaceutical chemistry, has more than twelve years of teaching experience. Currently, Head of Dept., Pharmaceutical Chemistry, Nazareth College of Pharmacy, Kerala, India. Have research interest on phytochemicals of pharmacological interest. Have published more than twenty-five research articles in various reputed journals and conducted and chaired many national level seminars in Pharmaceutical chemistry.

Sebastin V. Associate Professor has more than twelve years teaching experience and currently Head of Dept., Pharmaceutical Chemistry, Malik Deenar College of Pharmacy, Kerala, India. Have research interests in phytochemistry and ethnopharmacology. Published more than ten research articles in reputed national and international journals, also, conducted and chaired many national level seminars in Pharmaceutical chemistry.

Cite this article: Kumar KIA, Manickam MS, Sreejith M, Sebastin V. In Vitro and In Vivo Anti-Inflammatory Evaluation of the Whole Plant Extracts of Crotalaria Biflora (L). Pharmacog J. 2021;13(3): 620-5. 